IZA DP No. 8943

Unions and Collective Bargaining in the Wake of the Great Recession

John T. Addison

Pedro Portugal

Hugo Vilares

March 2015 


\title{
Unions and Collective Bargaining in the Wake of the Great Recession
}

\author{
John T. Addison \\ Durham University Business School, \\ University of South Carolina and IZA \\ Pedro Portugal \\ Banco de Portugal, \\ Universidade Nova de Lisboa and IZA
}

Hugo Vilares

Banco de Portugal

Discussion Paper No. 8943

March 2015

IZA

P.O. Box 7240

53072 Bonn

Germany

Phone: +49-228-3894-0

Fax: +49-228-3894-180

E-mail: iza@iza.org

\begin{abstract}
Any opinions expressed here are those of the author(s) and not those of IZA. Research published in this series may include views on policy, but the institute itself takes no institutional policy positions. The IZA research network is committed to the IZA Guiding Principles of Research Integrity.

The Institute for the Study of Labor (IZA) in Bonn is a local and virtual international research center and a place of communication between science, politics and business. IZA is an independent nonprofit organization supported by Deutsche Post Foundation. The center is associated with the University of Bonn and offers a stimulating research environment through its international network, workshops and conferences, data service, project support, research visits and doctoral program. IZA engages in (i) original and internationally competitive research in all fields of labor economics, (ii) development of policy concepts, and (iii) dissemination of research results and concepts to the interested public.
\end{abstract}

IZA Discussion Papers often represent preliminary work and are circulated to encourage discussion. Citation of such a paper should account for its provisional character. A revised version may be available directly from the author. 


\section{ABSTRACT}

\section{Unions and Collective Bargaining in the Wake of the Great Recession}

This paper provides the first definitive estimates of union density in Portugal, 2010-2012, using a unique dataset. The determinants of union density at firm level are first modeled. Next, we draw upon a very recent study of the union wage premium to provide summary estimates of the union wage gap for different ranges of union density. Since these estimates fully reflect the reality of an industrial relations system in which collective agreements are extended to nonunion workers and firms, the final issue examined is contract coverage. Although there has occurred a pronounced fall in the number of new extension agreements in recent years, this decline has been uncritically linked with a fall in coverage. We show that the number of workers covered by new and existing agreements has been largely unaffected by economic crisis. The reduced frequency of new agreements and extensions is viewed as an aspect of downward nominal wage rigidity in deflationary times (the counterpart of "upward nominal wage rigidity" in more normal times) rather than the immediate expression of a crisis in collective bargaining per se.

JEL Classification: J31, J52, J53

Keywords: collective bargaining, union density, collective agreement coverage, union wage premium, nominal wage rigidity, Portugal

Corresponding author:

John T. Addison

Darla Moore School of Business

University of South Carolina

1014 Greene Street

Columbia, SC 29208

USA

E-mail: ececaddi@moore.sc.edu 


\section{Introduction}

Portugal is one of a large number of countries where there are no published statistics on union density. The consequence is that prior estimates of union density for Portugal are little more than informed guesstimates. Fortunately, a solution to this problem has recently become available with the publication of the Relatório Único, or Single Report, conducted by the Office for Strategy and Planning (GEP) in the Ministry of Solidarity, Employment and Social Security. That is, we can now derive estimates of union density for the years 2010 through 2012. We provide the first estimates for Portugal using these new data. Even if there has occurred a steady erosion in union representation since 1980, we report broad stability over this three-year period and an average density of somewhat less than 11 percent. For its part, collective agreement coverage hovers either just above or below 90 percent over the same interval. The extension phenomenon that helps explain this disparity is addressed throughout the paper.

Having used the new data to provide economy-wide statistics on density, our cet. par. analysis then examines the determinants of density using all three years of data and a zero inflated negative count model in which the dependent variable is the number of unionized workers at firm level, given that some firms have no union employees. Among other things, we report that union density is highest in sectors and activities sheltered from product market competition.

The second part of our analysis presents a stylized version of a recent investigation into the union premium (see Portugal, Vilares, and Addison, 2014). That study explores a highdimensional fixed effects regression model and then offers a smoothed nonlinear function relating wages to union density at firm level. Our modification simply collapses that nonlinear relationship into five union density intervals.

As noted earlier, collective agreement coverage rates approximate 90 percent in Portugal by virtue of extension arrangements, whereby at the request of the union or the employer side the government has historically extended the terms of new agreements to the entire sector. Familiarly, such arrangements buttress union power in the marketplace by placing a floor under competition, and they also promote wage inflexibility/nominal wage rigidity through the setting of around 30,000 wage floors (see Martins, 2014).

One aspect of European crisis management affecting Portugal has been the joint therapy of fiscal consolidation and structural reforms geared to improving labor market competitiveness. 
The driving force behind these developments has been the Troika (comprising the European Commission, the European Central Bank, and the International Monetary Fund), which has linked the granting of loans and purchase of government bonds to the implementation of extensive structural reforms. The chief structural reforms sought by the Troika have included greater decentralization of collective bargaining, derogations from industry agreements at workplace level, close attention to what countries can afford in setting national minimum wages (i.e. linking increases to broad competitiveness and efficiency audits), and cutting back on extension agreements. In its dealings with the Troika in 2011, as we shall see, the Portuguese government agreed to a number of such measures. Most notably from the perspective of the present paper, extension agreements were initially frozen and the procedures for such extension subsequently reset by the government. (Additionally, any increase in the nation-wide minimum wage was meant to be made conditional on economic and labor market developments.)

At first sight, the data seem to suggest that the government measures on extension agreements have had a distinct chilling effect on collective bargaining. Thus, the number of new agreements has fallen dramatically and with them the number of extension agreements. (We trace the trends in new agreements and new extensions from 2008 to 2012.) It is just a short step to argue - as have a number of observers - that Portuguese collective bargaining is in crisis mode, in part because the collective bargainers are unwilling to enter into new agreements that will not be extended. But we choose instead to focus on the fact that, although new agreements have stalled, coverage under existing agreements (and operational extensions) has remained basically unchanged. Furthermore, since under law, new agreements cannot be less favorable to employees than the agreements they succeed, the decline in new agreements is less to be construed as a crisis in collective bargaining than of the difficulty in securing increases in nominal wages (that are admittedly less likely to be extended) in a deflationary environment. Real wages are not declining enough. In short, we can interpret fewer agreements and extensions as associated with downward nominal wage rigidity rather than the "upward nominal wage rigidity" experienced in more normal times. Upward nominal wage rigidity refers to the notion that in normal times many firms are obliged to increase the wages of their workers either through the extension of collective wage agreements or hikes in the minimum wage (see Martins, Guimarães, and Portugal, 2014).

The three themes of the paper are, therefore, union density and its determinants, the 
magnitude of the union wage gap, and collective bargaining coverage to include the implications of the sharp reduction in the frequency of new collective agreements and their extension. The plan of the paper is as follows. First, we provide a review of the Portuguese collective bargaining framework. Second, we describe the main datasets used in this inquiry and the base elements of the modeling strategy. Third, we present some introductory descriptives followed by the main findings of the paper. A short summary concludes.

\section{The Bargaining Framework}

Portuguese law makes provision for three types of collective bargaining at national, regional, and local level, although as we shall see it is the case that contemporary wage setting has been dominated by the widespread use of administrative instruments such as government extensions of agreements entered into by the bargaining parties. First, there is a modicum of firm-level bargaining signed by an individual company and one or more unions, resulting in so-called Acordos de Empresa (or AEs) that are important in the oil sector and transport and communications. Somewhat more important in terms of direct impact are collective agreements signed by several employers that are not part of an employers' association and one or more trade unions, known as Acordos Colectivos de Trabalho (or ACTs), that are significant in the financial sector and utilities. However, it is industry-level/branch or sectoral agreements, so-called Contratos Colectivos de Trabalho (CCTs), negotiated between one of more employers' associations and one or more unions, that predominate. As a result, CCTs in conjunction with extension agreements that are very largely are based on them (the other option is to extend ACTs) explain levels of collective bargaining coverage in the order of 90 percent of workers despite a marked decline in union density that the literature suggests extends back over 30 years (see Schnabel, 2013; Visser, 2013) and that we now estimate at around 11 percent. The vast majority of agreements are signed by unions linked to the two major union confederations: the CGPT-IN or General Confederation of Portuguese Workers, and the UGT or General Workers' Union. The gaps in coverage are largely in personal and other services, and in public administration where despite centralized negotiations between the government and the trade unions wages are decided upon unilaterally by the government. The wages of employees in publicly-controlled companies, such as public transportation and the postal service, are collectively bargained in the normal way. 
The industry-level or sectoral agreements may cover a range of industry-specific occupations but as the system does not rule out parallelism or overlapping collective agreements a single enterprise may be covered by two or more agreements depending on the union affiliation of the workers (although as a practical matter the content of most of the agreements is similar, the respective tables of wages tending to be the same). The situation may be further stratified if the firm in question straddles more than one line of economic activity, thereby belonging to one or more employer associations. As a result of fragmentation, therefore, several agreements may coexist for the same region, occupation, and firm. Observe that horizontal or occupation-based agreements are also possible, although they are infrequent largely because the law gives precedence to vertical sectoral agreements many of which are signed by a large number of primary unions that may include occupation-based unions.

Portuguese collective agreements are at once both extensive and general. They are extensive insofar as they cover many categories of worker. They are general in that they set only minimum conditions of which the most important is the base level monthly wage. (But they also cover other terms and conditions, most frequently working time, night work, overtime shift rates, and additional social benefits.) The focus is upon wage floors rather than anticipated wage growth that in in some centralized bargaining regimes (e.g. Sweden) have been incorporated directly into sectoral agreements. On average each agreement sets floors for around 100 job titles or categoria profissional. In consequence, employers have freedom of maneuver to tailor remuneration to their prevailing economic circumstances. ${ }^{1}$

Until recently, it has been the case that Portuguese collective agreements remain in place until a new agreement is signed. Coupled with the favor laboris principle that new agreements should yield more favorable conditions that those they are replacing, this has meant that collective agreements have tended to be revised regularly only insofar as wages are concerned, their other terms and conditions often being left untouched for many years. Recent changes in the labor code mean that collective agreements can now expire if they are not renewed. ${ }^{2}$

The most potent mechanism shaping the formation of wages has traditionally been the systematic extension via so-called Portarias de Extensão of industry-wide agreements (and occasionally ACTs) by the Ministry of Employment, following a request from either or both of the parties to the agreement. (Voluntary extensions are also common, while employers who sign an agreement with a trade union(s) usually extend its application to the entire workforce, 
irrespective of the worker's union status.) The upshot of this near automatic procedure is that even those wage agreements reached by trade unions and employers' associations with very low representation have had a strong impact in setting wage floors. Roughly speaking between 70 and 80 percent of the labor force have benefitted from collective agreements without being members of the organizations that signed them. Finally, in the absence of one of the representatives, or in the presence of strategic delays in negotiations/refusals to negotiate, the Ministry of Employment can regulate the sector directly through an Ordinance of Working Conditions, or Portarias de Condições de Trabalho. (An arbitration process, either mandatory or voluntary, may be set in motion to unfreeze 'blockages.') The extension mechanism in conjunction with the large number of job titles set down in the typical sectoral agreement together explain the 30,000 (informal) minimum wages identified in Martins' (2014) analysis of the employment and wage consequences of collective bargaining extensions referred to earlier.

In addition to the extension procedure, wage floors are also set under national minimum wage machinery, set up in 1974. The minimum wage can exceed that set under sectoral bargaining. This guaranteed monthly minimum wage (or RMMG) was virtually stagnant in real terms between 2002 and 2006, leading to an agreement between the social partners (government, the trade union confederations, and the employers' confederation) in 2006 allowing for an increase of almost 30 percent, to be phased in over five years and setting a medium-term target value $€ 500$ by 2011. It has been estimated that the share of minimum wage earners among fulltime workers aged 18 to 61 years rose dramatically from 6.7 percent of total employment in 2006 to 16.6 percent in 2010 (Carneiro, Guimarães, and Portugal, 2012: 451).

Both systems of minimum wages - nation-wide and collectively bargained/extended were disrupted by the economic crisis of 2011/12. As part of the Memorandum of Understanding $^{3}$ concluded between the Portuguese government and Troika in May 2011 it was agreed among other things that the procedures for extending collective agreements would be changed, even prior to which the government committed to restrict the extension of collective agreements. ${ }^{4}$ In October 2012 the government announced new criteria for the administrative extension of collective agreements taking into account the representativeness of the negotiating organizations and the implication of such extension for non-affiliated firms. Most importantly, agreements could only be extended if at least one union and one employers' organization requested it and the wider signatory organizations employed more than one-half of the 
employees in the relevant industry. However, in June 2014 this Resolution was modified: the criterion is now that the employers' association represents at least 50 percent of employees in the sector, or that its associates must include at least 30 percent of micro, small, and medium companies (employing up to 250 employees). As far as the national minimum wage was concerned, the Memorandum proposed to make any increase in the minimum wage conditional on economic and labor market developments. The minimum wage was duly frozen and in 2012 and 2013 it stood at the level of 2011 (viz. €485). It was not uprated to a little above the mediumterm target (originally set at €500) until October 2014.

The economic crisis and the response of the public authorities to it are credited with some fairly dramatic changes in Portuguese collective bargaining. In particular, the decline in the number of Portuguese collective agreements and worker coverage have been the subject of several critical EurWORK $(2013,2014)$ reports, while the topic of so-called radical decentralization affecting all crisis EU nations and leading to the "destruction of national collective bargaining systems” has been identified as a key paradigm shift by Schulten (2013) and Schulten and Müller (2013). That said, we note parenthetically that there has been little evolution in atypical collective agreements, by which is meant the ability of works councils and other representative bodies of workers at plant level to conclude collective agreements at the workplace. The current legal position is that works councils can negotiate at this level in firms with a minimum of 150 employees but only in circumstances where this is authorized by the trade union. The latter provision reflects the constitutional provision that competence to conclude collective agreements is the exclusive preserve of the trade unions. Reform proposals favoring so-called Acordo Geral de Empresa that can be signed independently of the trade union had to be abandoned in the face of strong union opposition in the Standing Council for Social Concertation or Comissão Permanente da Concertação Social (CPCS).

Social concertation/social dialogue is the final aspect of the bargaining framework identified here. Although the last pact establishing (a reference value for) nation-wide increases was in 1996, a number of agreements have been reached in the tripartite CPCS since its establishment in 1984. We earlier noted the 2006 accord on minimum wages. ${ }^{5}$ More importantly, the great plurality of proposals contained in the Memorandum relied significantly on a tripartite agreement of March 2011 on competitiveness and employment, while new reforms facilitating the renewal of fixed-term labor contracts, the elimination of four national holidays, 
and the excision of extra holiday time granted in compensation for to workers with no leave of absence in the previous year were agreed under a separate agreement on commitment to growth, competitiveness, and employment in January $2012 .{ }^{6}$ That said, the largest union confederation, the CGTP-IN, refused to sign either agreement. Moreover, there has been little movement in the area of atypical work, where the provisions on fixed-term contracts and temporary agency work remain unusually stringent; measures to promote decentralized bargaining envisaged under the Memorandum have only partially been implemented because of the need for union approval; and the representativeness of the parties' criterion as a condition for the extension of collective agreements has subsequently been diluted.

\section{The Data}

The main dataset used in the present inquiry is the Relatório Único for the three years 2010, 2011, and 2012. The data are collected through a mandatory questionnaire to every establishment with at least one wage earner, and the survey is conducted by the Office for Strategy and Planning in the Ministry of Solidarity, Employment and Social Security. The union question contained in the survey and asked of the manager respondent is as follows: "Indicate the number of workers for whom you have knowledge of their membership in a union (because they are union officials, because you deduct membership dues from their salary, or because the worker informed you about his/her membership so as to determine which particular collective regulation is applicable to their case)." Responses to this question are used to calculate the firm density rates.

Data are given on each establishment (its location, economic activity, employment, number of temporary employees, legal structure, and sales) and for each of its employees (their gender, age, education, skill, occupation, tenure, earnings, and work schedule). The earnings data are both detailed and accurate. The information pertains to the gross wage for normal hours of pay (or base wage) together with both regular and irregular benefits, overtime pay and hours, and wage bargaining mechanism/type of contract. The full-wage, or total compensation, is the wage variable used in estimating the union wage gap or premium. The accuracy of this information is assured by its administrative nature and the fact that by law the wage and all other information in the survey has to be made publicly available at the establishment. 
The restrictions imposed on the raw dataset were as follows. First, we limited our analysis to full-time workers in mainland Portugal. Second, we excluded workers from agriculture and forestry, as well as those in public administration whose wages are not collectively bargained. Third, individuals aged under 16 years and above 65 years at survey date were excluded. Finally, to be included workers' monthly wages had to be at least 80 percent of the mandatory minimum wage which here corresponds to the lowest admissible wage for apprentices. Our final sample for the density computations comprises some 612,336 year-firm observations, which correspond to some 301,724 firms matched by identifying number, representing 2,758,197 individuals matched by identifying number, gender, and year of birth, and 48,913 jobs matched by code of the collective agreement occupational category.

The data contained in the Relatório Único replicate that provided in the Quadros de Pessoal (Personnel Tables) but only became available in 2010. Computation of the union wage premium, will also use data from the three waves of the Relatório Único, but for our analysis of downward nominal wage rigidity in high and low inflation regimes, in which we effect a comparison between the years 1984 and 2012, data for the earlier year will be taken from the Quadros de Pessoal.

The third dataset used in this inquiry lists all new agreements and extensions of collective agreements between January 2008 and December 2011 and is maintained by the Ministry of Economics from the texts of both the individual collective agreements and extension orders. We simply take Martins' (2014) estimates based on these data as these are the most reliable indicators of the flow of collective agreements and extension ordinances available. ${ }^{7}$ These will be combined with stock data from the Relatório Único (and the Quadros de Pessoal) to examine the validity of the assertion that profound changes in the numbers of extensions and new agreements imply sharp falls in coverage.

\section{Modeling}

We address in turn the models used to estimate union density and the union wage gap - the final two components of our analysis having a basis in tabulations of collective agreements and extensions and investigation of the wage change distribution are not further discussed here. To estimate the determinants of establishment unionism we deploy a count regression model and, in recognition that many firms in the sample do not have any unionized workers $(287,056$ firms, or 
95.14 percent of the total), a zero inflated count model. More specifically, since the non-zero observations may be over-dispersed in relation to the Poisson distribution, we use a zero inflated negative binomial model (ZINB) after Lee, Wang, and Yau (2001).

The zero negative inflated negative binomial model can be written:

$$
\operatorname{Pr}(\mathrm{y} \mid \mathrm{x})=\left\{\begin{array}{cc}
\rho+(1-\rho) \mathrm{e}^{-\lambda(\mathrm{x}, \mathrm{u})} & \text { for } \mathrm{y}=0 \\
(1-\rho) \frac{\mathrm{e}^{-\lambda(\mathrm{x}, \mathrm{u})} \lambda(\mathrm{x}, \mathrm{u})^{\mathrm{y}}}{\mathrm{y} !} & \text { for } \mathrm{y} \geq 1
\end{array},\right.
$$

where $y$ denotes the count of the expected number of union workers at the establishment; $x$ are the covariates influencing unionization and $u$ is an error term; and $\rho \in[0,1]$ is a zero-inflated parameter, obtained through a simple logit parametrization:

$$
\rho=\frac{\exp (\tau)}{1+\exp (\tau)}
$$

Observed data often display empirical variances larger than their means, implying the existence of an “overdispersion” problem. This may reflect the existence of firm unobserved heterogeneity. The problem can be circumvented by adding the random variable $u$ to the vector of explanatory variables. This will allow for the expected value to differ from the variance. But conditional on the error $u, y$ follows a Poisson distribution. If we assume that $u$ follows a gamma distribution then the unconditional distribution of $y$ is a negative binomial. In other words, $\lambda(x, u)=$ $\exp \left(x^{\prime} \beta+\log u\right)$, with $u$ following a gamma distribution, and where $E(u \mid x)=1$ and $\operatorname{Var}(u \mid x)=1 / \delta$. Furthermore, we included an additional covariate, representing the size of the workforce as a measure of the exposure to the "risk" of being unionized, and forced the regression coefficient to be 1. That is, $\lambda(x, u)=\exp \left(x^{\prime} \beta+\log \mathrm{N}+\log u\right)$, where $N$ is number of workers in the firm. Proceeding this way, the specification lends itself to a convenient interpretation as a fractional regression model.

The dependent variable in the model is the number of unionized workers at the firm. The independent variables in the model are (average) worker characteristics and firm characteristics. The former comprise a continuous measure in age, and the proportions of females, foreign nationals, and individuals in various educational categories. The firm characteristics are the share of public equity, and dummies for establishment size (6) and industry (30). There are also two time dummies because of our use of all three waves of the Relatório Único. 
Our second model links union density to the union wage gap. It takes into account the results given by Portugal, Vilares, and Addison (2014) showing that it is unwise to assume that union density impacts linearly on (log) wages. That paper seeks to decompose the union wage gap in terms of the contribution of worker, firm, and job title heterogeneity via a highdimensional fixed-effects regression model. The main finding of the study is that the wage gap largely reflects the allocation of workers to firms with distinct wage policies due to the heterogenous presence of unions at firm/sector level rather than unobserved worker quality or differences among job titles, and we will take this interpretation as the main driving force behind the union wage gap. Observe that the union wage gap in this model - that is, prior to the decomposition exercise - gives the cet. par. average difference in wages at a given firm resulting from the specific union density rate of that firm via a two-stage estimation. Essentially the first step of the procedure is a wage regression with standard controls but a separate fixed effect corresponding to each level of union density in the database. That is, there is a different wage intercept capturing the constant impact of the firm's particular density rate on his or her compensation. In a second step, a kernel regression is used to smooth these fixed effects. The outcome of this exercise shows that the impact of union density is highly nonlinear. Specifically, it is miniscule up to 20 percent density but increases steeply thereafter, reaching a maximum at around 70 percent density.

As an approximation to the flexible functional form of the full model, our worker earnings function substitutes four union dummies (and the omitted category) for the 4,814 individual union fixed effects. Our estimating equation is thus specified as:

$$
\log w_{i f t}=\beta x_{i f t}+\sum_{k=1}^{4} \eta_{k} u d_{f t}^{k}+\varepsilon_{i f t},
$$

where $\log w_{i f t}$ is the $\log$ of monthly gross compensation for the individual worker $i$ in firm $f$ at year $t$ and, in addition to the union dummies, $x_{i f t}$ is a vector of explanatory variables and $\varepsilon_{i f t}$ denotes an idiosyncratic error term.

The four union density dummies ( $\left.u d_{f t}^{k}\right)$ are as follows: greater than zero but less than or equal to 25 percent, greater than 25 percent but less than or equal to 50 percent, greater than 50 percent but less than or equal to 75 percent; and greater than 75 percent. The base controls to be used at the level of the worker are age, age squared, tenure, tenure squared and dummy variables 
for gender, and education level; for the firm, they are industry and size dummies. In addition, there are two time dummies reflecting our use of all three waves of the Relatório Único. We shall also report separate summary results for an additional specification containing occupational dummies, reflecting the ongoing controversy in the literature as to their use (cf. Hirsch, 2004; Blanchflower and Bryson, 2003).

Finally, a caveat concerning needs to be entered in interpreting the union wage gap(s) reported here. Unions may indeed shape the wage policies of firms. But union presence is not random, so that the finding of a substantial premium may also reflect a union proclivity to organize firms with more generous compensation policies to begin with. Causation thus remains an issue in this study as in most others. That said, partial answers to the causation issue even in the absence of information on individual union status are provided by the fuller model where the wage gap is decomposed into its firm, job title and worker fixed effects.

\section{Introductory Descriptives}

We preface our cet. par. findings with some background statistics on union density and worker coverage by collective agreement. Table 1 provides three sets of estimates of trade union density covering the period 1980 to 2012. The first are taken from Blanchflower and Bryson (2003) and point to a sharp reduction (a little under 50 percent) in membership over the final two decades of the last century. The next set of estimates are broadly comparable in construction and are taken from the OECD (2015). They now show a much reduced rate of decline over the first decade of the present century and even a slight uptick as of 2012. As noted earlier, our own estimates rely on administrative data from the Relatório Único - rather than union sources - and exclude the public sector if not public enterprises. Perhaps more important than the difference between our data and those of the OECD, only partly by reason of this exclusion, is the broad stability in the measures of union density over the last three years for which the data are available in the face on economic crisis and retrenchment.

\section{(Table 1 near here)}

Table 2 plots the flow of collective agreements and their coverage from 2008 to 2012. This is where the real drama unfolds. As can be seen, there has been a precipitous fall in the numbers of new sectoral agreements (79.1 percent), multi-company agreements (66.7 percent), and single-firm agreements (58.8 percent) over just four years. Equivalently, the number of 
workers covered fell by 83.6 percent, 43.6 percent, and 85.7 percent, respectively. On aggregate, the number of workers covered directly by collective agreements fell from 1,894,846 to 327,622 (or 82.7 percent). The last column of the table reveals an even more dramatic fall off in the number of extension agreements of 92.7 percent. The table does not give the number of workers affected by these extension agreements as the authorities do not collect information about the number of affiliated workers in each signatory union and the universe of workers potentially covered by a given bargained instrument of collective bargaining. As a result, the available information simply reports the workers covered by each instrument independently of its origin, either by affiliation or extension.

(Table 2 near here)

The latter data have been interpreted as indicating a major rupture of the industrial relations system in Portugal that have excluded large numbers of workers from collective agreements. But the notion that the Portuguese reforms have resulted in an overall reduction in the coverage of collective agreements (see, for example, EurWORK, 2013, 2014; International Labor Organization, 2014; Schulten, 2013; Schulten and Müller. 2013) is to confuse flows with stocks, namely the number of workers covered by new agreements and extension orders and those covered by existing agreements and ordinances. In short, Table 2, dealing with flows, will have to be augmented with stock data in what follows, and to anticipate our findings we shall report that the number of workers covered by collective agreements has, in common with union density, evinced broad stability in recent years. We shall also argue that there is little evidence in the flow data to herald the disappearance of collective bargaining.

\section{Main Findings on Union Density, the Wage Gap, and Stock Data on Coverage}

Table 3 presents the regression estimates from the negative binomial model discussed in section IV. ${ }^{8}$ Observe firstly the positive relationship between average age and the number of unionized workers in the firm, indicating the increased propensity on the part of the worker to become unionized with age. The negative association between membership and nationality (here the share of foreigners) is also familiar. Less anticipated is positive association between the share of females in the firm and union density, although it is only marginally significant. (The coefficient estimate of 0.0710 means that increasing the share of females by 10 percentage points increases union density by 0.07 percent.) Evidently, traditional gender-based supply and demand have 
become moot with the increased labor market exposure of females. For its part education is strongly associated with union membership: the relationship is near monotonic, the omitted category being those with no schooling.

(Table 3 near here)

Perhaps the clearest association of all is the monotonic relation between firm size and union membership, most likely reflecting scale economies to unions in the supply of union services, as well as potential collective voice benefits. Note, too, the sharply higher membership rates in companies with greater public equity. It is frequently argued that the 'dispersed' nature of property rights in such circumstances together with implicit guidelines on collective bargaining operating in public administration (not included in the sample), where government assumes the position of employer, provides encouragement to higher union density in publicly owned firms.

Finally, among the sectoral dummies, the cases of Finance and Insurance Services and Transportation and Storage Services are important. The former sector is the sole private sector industry where the labor unions offer a system of private healthcare benefits to workers, while the latter is well known for its inelastic demand, small share of labor costs in total costs, and pervasive featherbedding. Other important sectors are Oil Refined Products and Electricity and Water, oligopolistic sectors with an historical prominence of public equity, which despite its erosion under successive privatization schemes likely has legacy effects on collective bargaining arrangements.

We turn next to the association between union density and the union wage gap, using the modified (first-stage) procedure from Portugal, Vilares, and Addison (2014), described earlier, in which four density dummies substitute for individual union fixed effects in each worker's wage equation. Table 4 summarizes the model in presenting regression coefficients for the density dummies ( $>0 \%, \leq 25 \% ;>25 \%, \leq 50 \% ;>50 \%, \leq 75 \%$; and $>75 \%$ ), the omitted dummy being union density $=0 \%$. Summary results from four separate specifications are reported. The first contains just the union density dummies; the second adds a set of worker controls; the third adds firm controls; and the fourth adds a single control for occupation. It will be recalled that in addition to the occupational control, the worker controls consist of age and age squared, tenure and tenure squared, and dummy variables for gender and educational level while the firm arguments are industry and size dummies 
(Table 4 near here)

As can be seen from Table 4, after density climbs above one-quarter of the firm's workforce, the union premium is sizeable and survives the incorporation of worker, firm and occupational controls. For example, absent controls, in those workplaces where more than 75 percent of the workforce is unionized the average value of the premium is 61.11 percent. With the addition of worker and firm controls, the corresponding values are less at 34.0 and 14.95 percent, respectively, indicating that union workers are more highly educated and the importance of a firm's location and size. Finally, adding in occupation controls causes a no appreciable change in the premium, indicating that for this dataset the controversy over the inclusion of the occupational controls in the augmented Mincerian wage equations is perhaps overdrawn.

These estimates of the union premium are really rather substantial. If an analogy can easily be drawn, they certainly exceed U.S. plant-based estimates based on material victories in union representation elections (see Lee and Mas, 2012).

This returns us to the issue of coverage. In Table 2 we reported the dramatic fall-off in new agreements and new extension ordinances after 2010, drawing on Martins (2014). Other observers have misleadingly concluded from these data that the changes since 2008 have left a little over 1.5 million workers without coverage and that the decline in collective bargaining has reached crisis point (EurWORK, 2014). In Table 5, using data from the Relatório Único for 2010-2012 and from the Quadros de Pessoal for 2008-2009, we report that the number of workers covered by an existing or new instrument of collective bargaining - either agreement or extension ordinance - has declined only modestly from a peak of 91.5 percent of all workers to 89.2 percent of all workers in 2012. We supplement the material in Table 5 with information on the component instruments in Figure 1 which also gives information on the total number of workers affected. The most notable feature of the figure is the broad-based stability in the coverage of the various types of agreements over the sample period. Clearly, the bulk of extension agreements are assigned here to branch agreements or CCTs. Accordingly, the 'other' category picks up the other non-bargained instruments such as Regulations of Working Conditions and arbitration where the Ministry of Employment, or an independent third party, regulate the sector directly and not just orders that simply enlarge the franchise of a bargained instrument.

(Table 5 and Figure 1 near here) 
The bottom line with respect to coverage is that reports of the death of Portuguese collective bargaining have greatly been exaggerated by outside observers. This interpretation is underscored by the subsequent dilution of the restrictions on extension agreements. We next proceed to offer a different explanation for the decline in new agreements and extension ordinances.

\section{Collective Bargaining Coverage Once More (or Downward Nominal Wage Rigidity in High and Low Inflation Regimes)}

The notable feature of wage setting in recent years, and in particular at end of our sample period, is the evidence of extreme nominal wage rigidity. This outcome is the result of a conflation of severe economic contraction and a low rate of inflation. In these circumstances, a revealing exercise is to contrast the nominal wage change distribution in 2012 with that in 1984 when another interval of economic recession was accompanied by high inflation. The respective wage change distributions (of job stayers) are provided in panels (a) and (b) of Figure 2. We focus here on the base wage since this measure is more closely related to the theoretical notion of a negotiated wage rate.

Beginning with panel (a) of the figure, it can be seen that a tiny (2\%) proportion of workers faced nominal cuts and a discernible share of worker (5\%) experienced a wage freeze. However, the large majority of workers had nominal wage increases but real wage cuts. Only $18 \%$ of workers enjoyed real wage increases, namely those located in the wage change distribution to the right of the inflation rate identified by the vertical dashed line. The share of workers located between the two vertical lines (74\%) provides a rough indication of real wage contractual flexibility in the face of recession. On net, therefore one can speak of real wages having declined by 7.4 percent in 1984, much more than the decline in real GDP (-1\%). Meantime, the unemployment rates increased very modestly from 8.2 to 8.5 percent (see also Carneiro, Guimarães, and Portugal, 2012).

The drama of contemporary wage adjustment is illustrated in panel (b) of the figure. The wage change distribution nearly collapses at zero percent nominal wage change. Fully 86 percent

of the workers experienced real wage decreases. Because the inflation rate was very low, the margin of downward real wage adjustment that would not imply nominal wage cuts was highly 
circumscribed. In these circumstances, a huge fraction of workers experienced nominal wage freezes (76\%), an outcome without parallel in other developed economies. Overall, real wages fell by 1.3 percent in 2012 whereas GDP declined by 3 percent. Meantime, the unemployment rate increased substantially from 12.7 to 15.5 percent. Some other reasons why nominal wage were effectively frozen have already been discussed. They have to do with the mechanisms that generate automatic nominal wage increases, in the form of a sharp decline in new collective agreements, legal limits placed on the extension of such agreements, and a freeze on minimum wage hikes. In short, 2012 was a time in which incipient downward nominal wage rigidity became truly binding, the full consequences of which are to be felt in the future. These consequences include job destruction (Carneiro, Portugal and Varejão, 2014), pent-up wage deflation, and then and only then the crisis in industrial relations referred to by EurWORK, inter al.

\section{Conclusions}

This inquiry has uncovered what to many will be some surprising facts about collective bargaining in Portugal. This is largely the result of our being able to use a new dataset that contains reliable data on union membership. We provide not merely the first accurate estimates of union density in Portugal, 2010-2012, but also demonstrate evidence of a sizeable densityrelated union premia in a regime of near-universal coverage. Causality remains an issue because unions may locate in firms with more generous compensation policies or that are more 'permeable' to union wage demands. Finally, despite an unambiguous shift in bargaining momentum that has led to far fewer collective agreements and extensions in the wake of the economic crisis, we report that coverage by collective agreement is largely unaffected once one accounts for the stock of existing contracts. Although the bargaining milieu has changed, we argue that this is best seen as a consequence of a low inflation regime in conjunction with a severe economic downturn. Whereas in the past the wage setting system was largely driven by "upward nominal wage rigidity" the present environment is one in which downward nominal wage rigidity has become truly binding. If not exactly a case of plus ça change, we have yet to observe a sea-change in Portuguese collective bargaining practice. That said, our analysis suggests that changes will be forced on the bargaining parties. 


\section{Endnotes}

${ }^{1}$ On the determinants of the contractual wage and the 'wage cushion,' or difference between actual and the contractual wage set for each worker category, see Cardoso and Portugal (2005).

2 The status quo ante until late 2014 was as follows. Collective agreements expired five years after they had last been agreed, or five years after one of the parties had indicated its intention to renegotiate their terms and conditions. The said, the collective agreement would continue to apply for at least 18 months after this, to allow negotiations to take place. Indeed, either of the parties had a period of 12 months during which to request the appointment of an arbitrator to draw up new terms and conditions. New validity rules for expired collective agreements came into force on 1 September 2014. Specifically, the expiry period was reduced from five years to three years, and the period of continuation upon expiry reduced from 18 months to 12 months. In addition, whenever there is an interruption of negotiations, including conciliation, mediation or voluntary arbitration for more than 30 days, the period of 'survival' is suspended and the period of negotiation with suspension cannot exceed 18 months.

${ }^{3}$ The terms of the Memorandum are available at http://economico.sapo.pt/public/uploads/memorandotroika_04-05-2011.pdf.

${ }^{4}$ Other changes under the Memorandum were revisions to the unemployment insurance system in terms of the level and duration of benefits, a diminution in employment protection via a reduction in severance payments and the relaxation of protection against individual dismissals, a reduction in the payment for overtime working and an increase in hours by reducing compensatory time off per hour of overtime, and an expansion of flexible working time arrangements in the form of working time accounts at individual and plant level.

${ }^{5}$ See also the 2008 agreement on the Regulation of Labor Relations, Employment Policies and Social Protection. Available at: http://www.ugt.pt/Acordo_25_06_2008.pdf

${ }^{6}$ The two accords are available at http://www.ces.pt/download/719/AcordoTripCompetEmprego.pdf and http://www.portugal.gov.pt/media/424132/compromisso_crescimento_competitividade_emprego .pdf. And for English language summaries of labor law, see Palma Ramalho (2013). 
7 The reader is also referred to EurWORK (2013, 2014) and Dias and Cerdeira (2011) who use published estimates by the Directorate-General for Employment and Labor Relations (DirecçãoGeral do Emprego e das Relações de Trabalho, or DGERT). DGERT is a central office of state charged with the responsibility to assist in the development of policies regarding employment, training and professional certification, and occupational health and safety. It is also responsible for monitoring and promoting collective bargaining and the prevention of collective labor disputes.

${ }^{8}$ In general, the coefficient estimates can be interpreted within the framework of a fractional regression model, where the fraction of integers is the number of unionized workers divided by the total number of workers within the firm. In other words, union membership is seen as the outcome of a Bernoulli trial with probability $p$ which at the firm level corresponds to union density. 


\section{References}

Blanchflower, David, and Alex Bryson. 2003. "Changes over Time in Union Relative Wage Effects in the U.K. and the U.S.A. revisited." In John T. Addison and Claus Schnabel (eds.), International Handbook of Trade Unions. Cheltenham and Northampton: Edward Elgar, pp. 197245.

Cardoso, Ana Rute, and Pedro Portugal. 2005. "Contractual Wages and the Wage Cushion under Different Bargaining Settings.” Journal of Labor Economics 23(4): 875-902.

Carneiro, Anabela, Paulo Guimarães, and Pedro Portugal. 2012. "Real Wages, and the Business Cycle: Accounting for Worker, Firm, and Job Heterogeneity.” American Economic Journal: Macroeconomics 4(2): 133-152.

Carneiro, Anabela, Pedro Portugal and José Varejão. 2014. “Catastrophic Job Destruction.” Journal of Macroeconomics 39(Part B): 444-457.

Dias, João, and Maria da Conceiçao Cerdeira. 2011. "Recent Trends in Wages and Collective Bargaining in Portugal.” Sociologia On Line 2: 345-367

Hirsch, Barry T. 2004. "Reconsidering Union Wage Effects: Surveying New Evidence on an Old Topic.” Journal of Labor Research 25(2): 233-266.

EurWORK. 2013. "Dramatic Decline in Collective Agreements and Worker Coverage.” Dublin: European Foundation for the Improvement of Living and Working Conditions. Available at: http://eurofound.europa.eu/observatories/eurwork/articles/industrial-relations/dramatic-declinein-collective-agreements-and-worker-coverage.

EurWORK. 2014. "Portugal: Decline in Collective Bargaining Reaches Critical Point.” Dublin: European Foundation for the Improvement of Living and Working Conditions.” Available at: http://www.eurofound.europa.eu/observatories/eurwork/articles/working-conditions-industrialrelations/portugal-decline-in-collective-bargaining-reaches-critical-point.

International Labor Organization. 2014. “Tackling the Jobs Crisis in Portugal.” ILO Studies on Growth with Equity. Geneva: ILO.

Lee, David S., and Alexandre Mas. 2012. "Long-Run Impacts of Unions on Firms: New Evidence from Financial Markets, 1961-1999.” Quarterly Journal of Economics 127(1): 333378.

Lee, Andy H., Kui Wang, and Kelvin K.W. Yau. 2002. Analysis of Zero-Inflated Poisson Incorporating Extent of Exposure.” Biometrical Journal 43(8): 963-975.

Martins, Fernando, Paulo Guimarães, and Pedro Portugal. 2014. "Upward Nominal Wage Rigidity.” Unpublished Paper, Banco de Portugal.

Martins, Pedro S. 2014. "30,000 Minimum Wages: The Economic Effects of Collective Bargaining Extensions.” IZA Discussion Paper No. 8540. Bonn: Institute for the Study of Labor. 
OECD. 2015. “Trade Union Density,” OECD StatExtracts. Available at http://stats.oecd.org/Index.aspx?DataSetCode=UN_DEN.

Palma Ramalho, Maria do Rosário. 2013. "Portuguese Labor Law and Industrial Relations During the Crisis.” Working Paper No. 54.Geneva: International Labor Office.

Portugal, Pedro, Hugo Vilares, and John T. Addison. 2014. "The Sources of the Union Wage Gap.” Unpublished Paper, Banco de Portugal.

Schnabel, Claus. 2013. "Union Membership and Density: Some (Not So) Stylized Facts and Challenges.” European Journal of Industrial Relations 19(3): 255-272.

Schulten, Thorsten. 2013. "The Troika and Multi-Employer Bargaining - How European Pressure is Destroying National Collective Bargaining Systems." Available at: http://www.socialeurope.eu/2013/06/the-troika-and-multi-employer-bargaining/

Schulten, Thorsten, and Torsten Müller. 2013. “A New European Interventionism? The Impact of New Economic Governance on Wages and Collective Bargaining. In Social Developments in EU 2012, edited by David Natali and Bart Vanhercke, pp. 181-213. Brussels: European Trade Union Institute and the European Social Observatory.

Visser, Jelle. 2013. "Database on Institutional Characteristics of Trade Unions, Wage Setting, State Intervention and Social Pacts." Version 4.0, http://www.uva-aias.net/207. 


\begin{tabular}{|c|c|c|c|c|c|c|c|c|c|c|}
\hline \multirow[b]{2}{*}{ Study } & & & & & $Y \epsilon$ & & & & & \\
\hline & 1980 & 1990 & 1995 & 1998 & 2000 & 2005 & 2008 & 2010 & 2011 & 2012 \\
\hline $\begin{array}{l}\text { Blanchflower and } \\
\text { Bryson (2003) }\end{array}$ & 52 & 40 & 30 & 25 & - & - & - & - & - & - \\
\hline $\operatorname{OECD}(2015)^{\mathrm{a}}$ & - & - & - & - & 21.6 & 21.3 & 20.5 & 19.3 & 19.5 & 20.5 \\
\hline This study ${ }^{b}$ & - & - & - & - & - & - & - & 10.9 & 10.4 & 10.6 \\
\hline \multicolumn{11}{|c|}{ 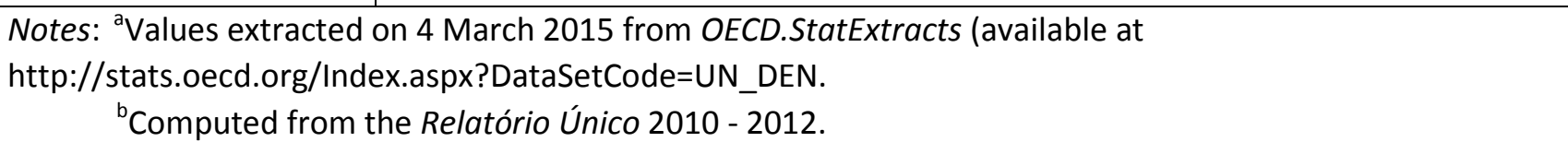 } \\
\hline
\end{tabular}




\begin{tabular}{|c|c|c|c|c|}
\hline \multirow[b]{2}{*}{ Year } & \multicolumn{3}{|c|}{ Type of Collective Agreement } & \multirow{2}{*}{$\begin{array}{l}\text { Extension } \\
\text { (PEs) }\end{array}$} \\
\hline & $\begin{array}{c}\text { Sectoral } \\
\text { (CCTs) }\end{array}$ & $\begin{array}{l}\text { Multi- } \\
\text { Employer } \\
\text { (ACTs) }\end{array}$ & $\begin{array}{l}\text { Company } \\
\text { Agreements } \\
\text { (AEs) }\end{array}$ & \\
\hline 2008 & $\begin{array}{c}172 \\
(1,778,216)\end{array}$ & $\begin{array}{c}27 \\
(47,232)\end{array}$ & $\begin{array}{c}97 \\
(69,398)\end{array}$ & 178 \\
\hline 2009 & $\begin{array}{c}142 \\
(1,299,371)\end{array}$ & $\begin{array}{c}22 \\
(59,902)\end{array}$ & $\begin{array}{c}87 \\
(37,952)\end{array}$ & 128 \\
\hline 2010 & $\begin{array}{c}141 \\
(1,309,267)\end{array}$ & $\begin{array}{c}25 \\
(64,455)\end{array}$ & $\begin{array}{c}64 \\
(33,344)\end{array}$ & 140 \\
\hline 2011 & $\begin{array}{c}93 \\
(1,160,080)\end{array}$ & $\begin{array}{c}22 \\
(52,737)\end{array}$ & $\begin{array}{c}55 \\
(24,102)\end{array}$ & 24 \\
\hline 2012 & $\begin{array}{c}36 \\
(291,068)\end{array}$ & $\begin{array}{c}9 \\
(26,645)\end{array}$ & $\begin{array}{c}40 \\
(9,909)\end{array}$ & 13 \\
\hline \multicolumn{5}{|c|}{$\begin{array}{l}\text { Source: Martins (2014, Table } 2) \text {. } \\
\text { Notes: Numbers of collective agreements, and workers covered (in } \\
\text { parentheses). Earlier values are reported by Dias and Cerdeira (2011); } \\
\text { and for slightly different values, see EurWORK }(2013,2014) .\end{array}$} \\
\hline
\end{tabular}




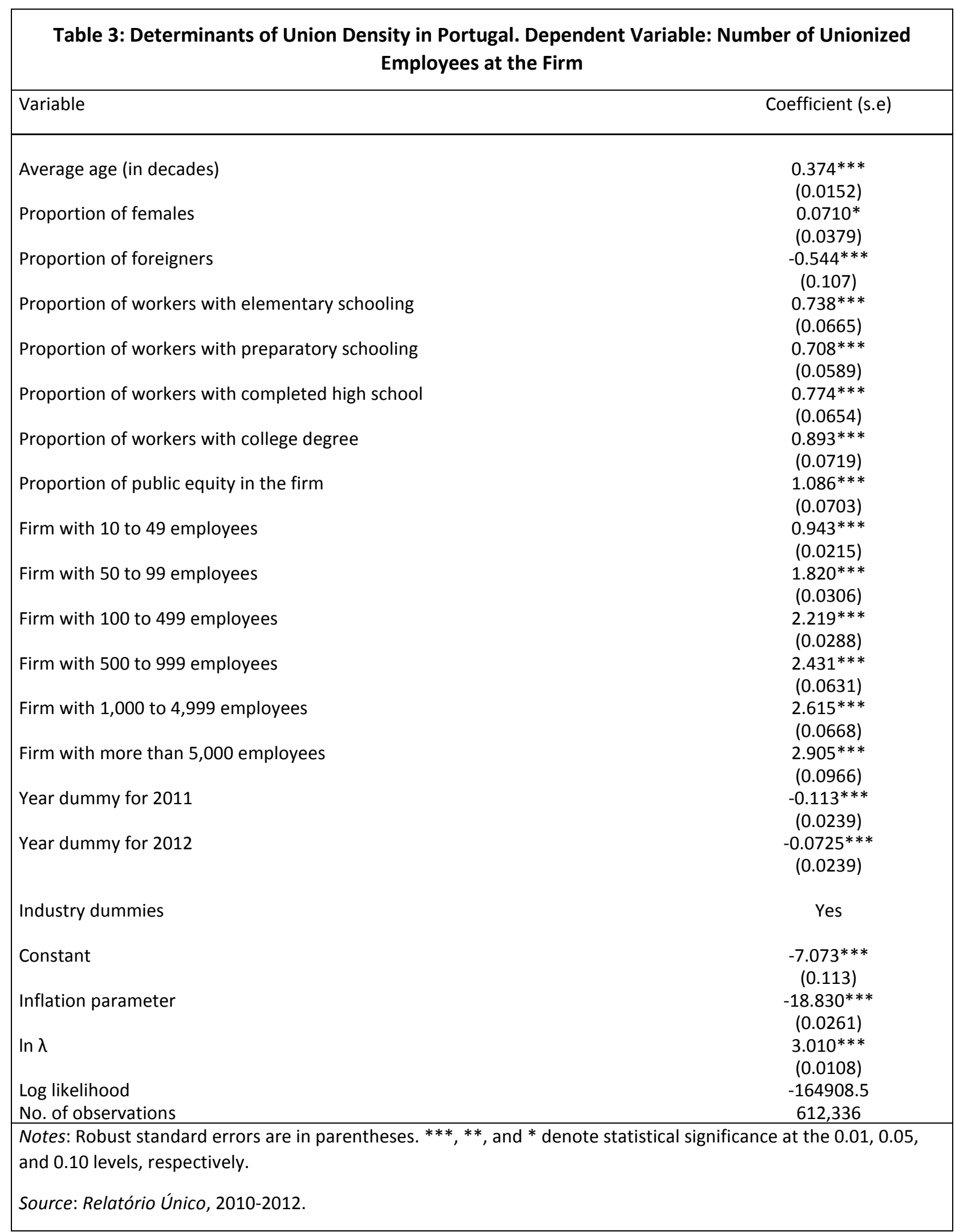




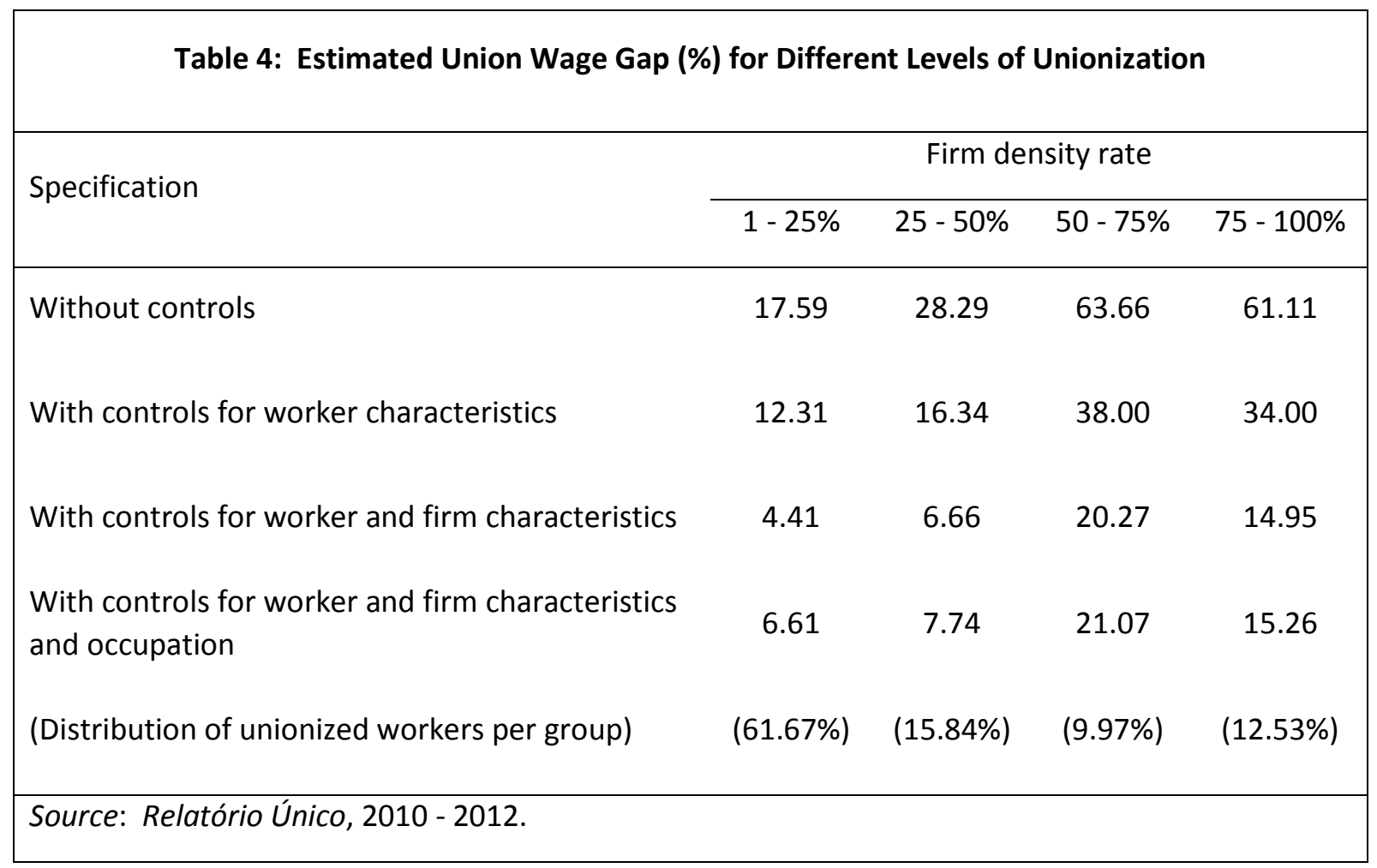

\begin{tabular}{|cc|}
\hline \multicolumn{2}{|c|}{$\begin{array}{c}\text { Table 5: Workers Covered by an Instrument } \\
\text { of Collective Bargaining in Portugal }\end{array}$} \\
\hline Year & $\begin{array}{c}\text { Union } \\
\text { coverage }\end{array}$ \\
\hline 2008 & 90.6 \\
2009 & 90.5 \\
2010 & 91.5 \\
2011 & 91.0 \\
2012 & 89.2 \\
\hline Sources: Quadros de Pessoal, 2008-2009; Relatório Único, 2010-2012 \\
\hline
\end{tabular}




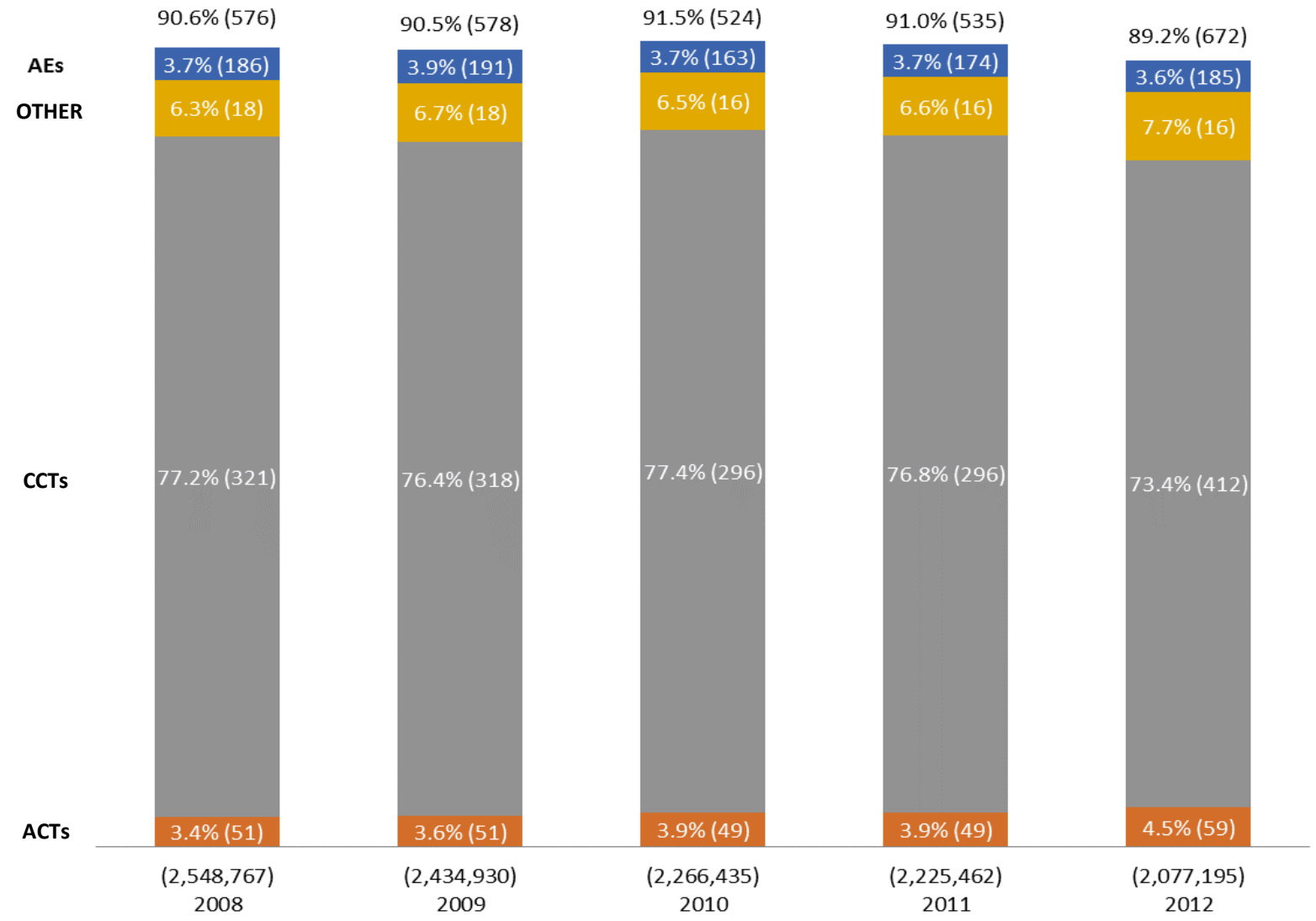

Notes: Percentage values indicate the employment coverage share of each respective instrument/all instruments. Figures in parentheses indicate the number of each respective instrument/all instruments. Figures at base of each column in brackets above year indicate the total numbers of workers covered.

Sources: Quadros de Pessoal, 2008-2009; Relatório Único, 2010-2012. 
(a) Wage Change Distribution, 1984 (inflation rate $=27.1 \%$ )

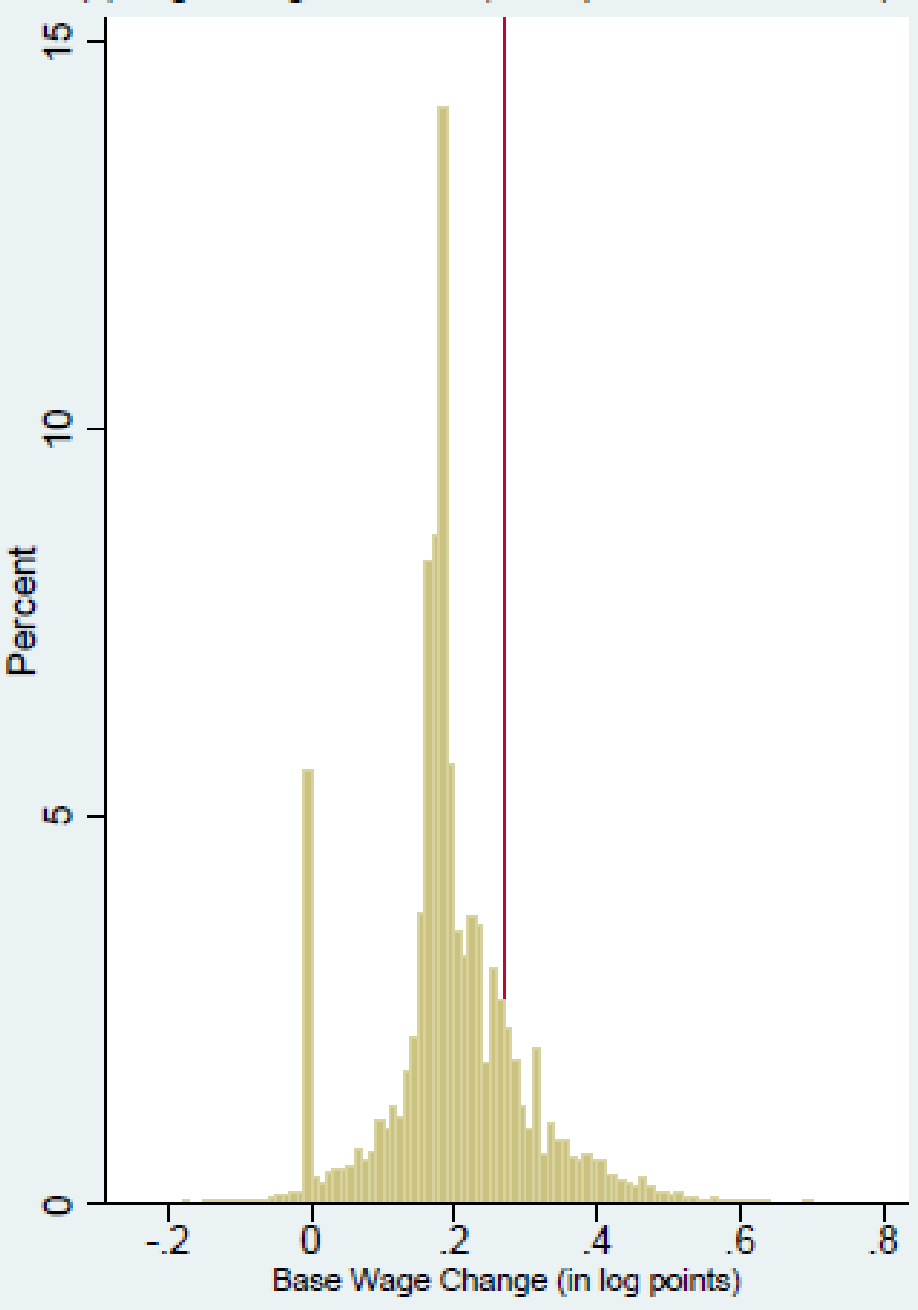

(b) Wage Change Distribution, 2012 (inflation rate $=2.1 \%$ )

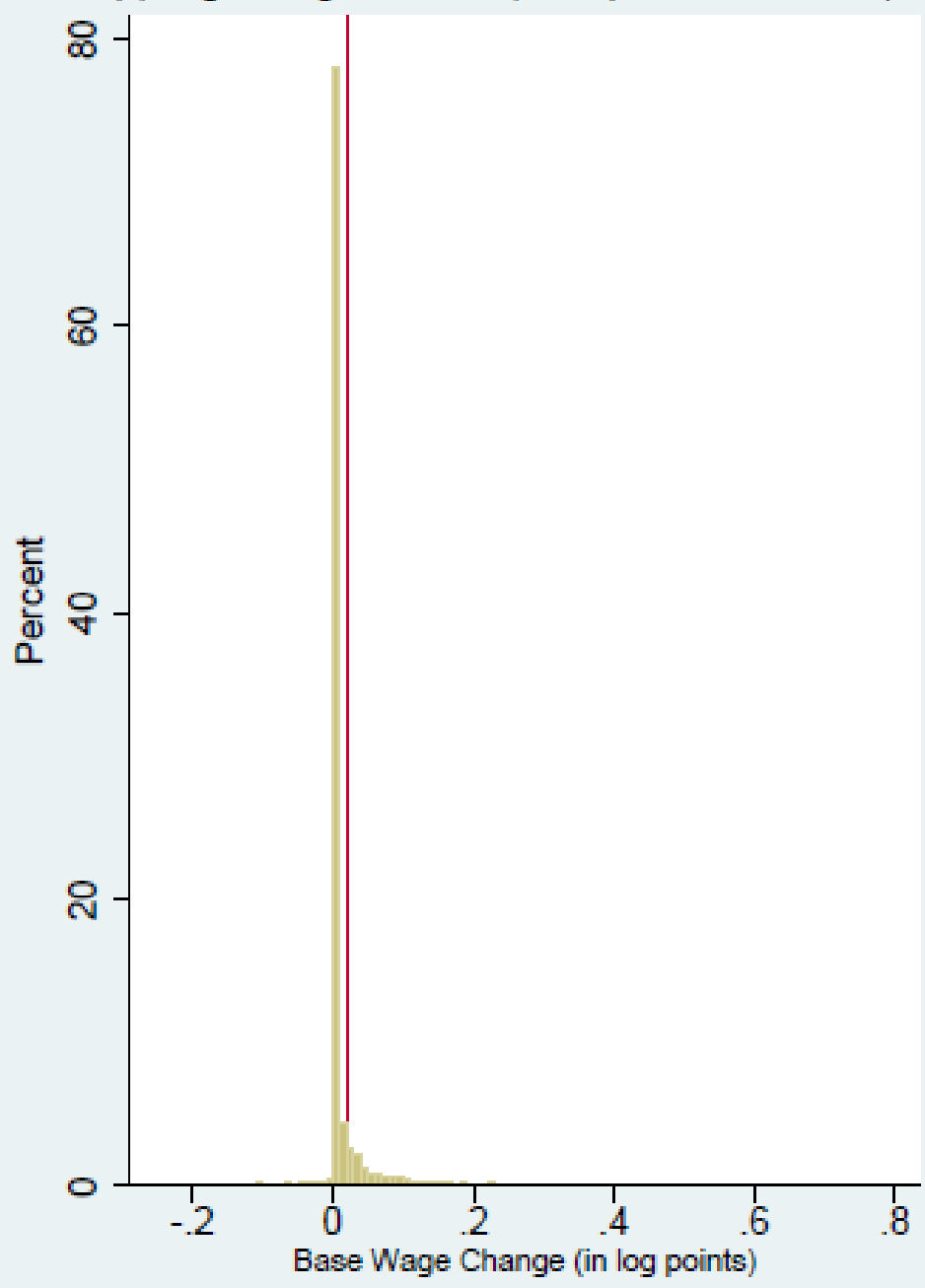

Sources: Quadros de Pessoal, 1984; Relatório Único, 2012. 